Research Report

\title{
The Effect of Addition of Bambusa Arundinacea (Retz.) Willd. Fibers to Heat- Cured Acrylic Resin on Impact Strength
}

\author{
Chanita Elonianty, Titien Hary Agustantina, Intan Nirwana \\ Department of Dental Material \\ Faculty of Dental Medicine, Universitas Airlangga \\ Surabaya - Indonesia
}

\begin{abstract}
Background: The prevalence of acrylic resin dentures fracture due to accidental drop is relatively high especially when it is being cleaned by patient. The effort to strengthen acrylic resin denture was done by adding Bambusa arundinacea (Retz.) Willd fibers, which was based on previous research. It has been proven that the addition of bamboo fiber to self-cured acrylic resin can increase the tensile strength. It has acceptable tensile properties, relatively low cost, high toughness, and good thermal properties. Purpose: To determine the impact strength of heat-cured acrylic resin after the addition of Bambusa arundinacea (Retz.) Willd. fibers at various lengths and weights. Methods: Bambusa arundinacea (Retz.) Willd. fibers with lengths of $2 \mathrm{~mm}, 6 \mathrm{~mm}, 12 \mathrm{~mm}$ and weights of $3 w t \%$, 6wt $\%$, 9wt\% were added to heat-cured acrylic resin. The impact strength of heat-cured acrylic resin was tested using the Charpy method with mini impact tester KRY type. The test results were calculated using the impact strength formula. The research data were analyzed using oneway anova test and Tukey HSD test. Results: The data analysis showed that there was a significant difference in impact strength of heat-cured acrylic resin after the addition of Bambusa arundinacea (Retz.) Willd fibers. Conclusion: Addition of Bambusa arudinacea (Retz.) Willd. fibers increased the impact strength of heat-cured acrylic resin respective to the increment of length and weight of Bambusa arudinacea (Retz.) Willd. fibers.
\end{abstract}

Keywords: Bambusa arundinacea (Retz.) Willd fibers, heat-cured acrylic resin, impact strength, denture base.

Correspondence: Titien Hary Agustantina, Department of Dental Material, Faculty of Dental Medicine, Universitas Airlangga, Jl. Prof. Dr. Moestopo No. 47 Surabaya 60132 - Indonesia. Telp: +62315030255 Email: titien-h-a@fkg.unair.ac.id

\section{INTRODUCTION}

Acrylic resins have been used as a denture base since the mid-1940s. ${ }^{1}$ Acrylic resin has become the first choice because it has an excellent aesthetic quality, affordable cost, easy to manipulate, and low density. Acrylic resin has several disadvantages such as inadequate strength, low thermal conductivity, susceptibility to distortion, and radiolucent appearance on radiographic image. ${ }^{2}$

Acrylic resin denture base treatment must be carried out routinely to prevent debris, stains, plaque, and bacteria. Patients are advised to clean the acrylic resin dentures by brushing or soaking. Acrylic resin denture base fractures may present due to an accidental drop, especially during the cleaning process. ${ }^{3}$ The prevalence of fracture dentures due to an accidental drop is $46 \%{ }^{4}$. The resistance of denture bases to fractures is related to the impact strength function of acrylic resin material. ${ }^{5}$ The prevalence of impact strength failure of acrylic resins is $80.4 \%{ }^{6}$

The effort to strengthen acrylic resin dentures is made by adding fiber called fiber-reinforced composite (FRC).
The commonly used fiber-reinforced composites are fiber glass, carbon, aramid, and ultra high molecular weight polyethylene. 2 The FRC component provides strength and stiffness that the surrounding matrix supports the strengthening process and can improve the function of the material added with $\mathrm{FRC}^{7}$ The lacks of FRC, among others, are relatively difficult to obtain and relatively expensive price. Considering lacks FRC, it is necessary to find an alternative material that can replace the FRC function.

The effort to improve the strength of acrylic resin dentures is done by adding fiber called Bambusa arundinacea (Retz.) Willd. fiber Bamboo contains natural fibers which can be used as an alternative material to replace FRC in improving the strength of a material. The advantages of bamboo fiber include tensile nature, relatively low cost, high toughness, and good thermal properties. ${ }^{8}$ Bamboo fiber is environmentally friendly and biocompatible. ${ }^{9}$ Bamboo fiber can be added to non-dental materials, i.e. polypropylene and epoxy. Adding bamboo fiber added to polypropylene produces high tensile strength and modulus of elasticity with an optimum length of 10-20 $\mu \mathrm{m} .{ }^{10}$ The 
addition of bamboo fiber soaked in alkaline solution to polypropylenene improves the tensile strength, transverse strength, and modulus of elasticity respective to the bamboo fiber weight with an optimum weight of $40 \mathrm{wt} \% .^{11}$

Bamboo fiber added to the epoxy shows improved impact strength, but it is greatly influenced by the size and weight of the fiber used. Impact strength improved in bamboo fibers with a length of $4 \mathrm{~mm}$ and a weight of $20 \mathrm{wt} \% .^{12}$

Bamboo fiber can be added to self-cured acrylic resin. Bamboo fibers of different lengths and weights can affect the tensile properties of self-cured acrylic resins used in dental applications. The addition of bamboo fiber shows that the tensile strength and modulus of elasticity improves respective to the increasing weight and length of bamboo fiber on self-cured acrylic resin. The optimum length bamboo fiber $12 \mathrm{~mm}$, and the optimum weight is $9 \mathrm{wt} \%{ }^{13}$

This study aimed to examine the effect the addition of Bambusa arundinacea fiber on heat-cured acrylic resin on impact strength. This was motivated by the relatively high prevalence of denture base fractures due to accidental drop during the cleaning process.

\section{MATERIALS AND METHODS}

The materials used in this study were Bambusa arundinacea (Retz.) Willd. fiber, $\mathrm{NaOH} 5 \%, \mathrm{CH} 3 \mathrm{COOH}$, distilled water, heat-cured acrylic resin (Triplex Hot, Germany), gypsum type 2, and gypsum type 3 . The tools used in this study were paper cutting tools, oven, digital scale, brass master models with the size of $65 \mathrm{~mm} \times 10 \mathrm{~mm}$ x $2.5 \mathrm{~mm}$, metal cuvette, hydraulic press, hand-press, and mini impact tester KRY type (ITS, Surabaya).

The research was divided into two stages, namely the fabrication of Bambusa arundinacea (Retz.) Willd. fiber and heat-cured acrylic resin plates. Stages of fabrication of Bambusa arundinacea (Retz.) Willd. fiber was as follows, a stem of Bambusa arundinacea (Retz.) Willd. was cut with a saw at length of $100 \mathrm{~cm}$. The stem of Bambusa arundinacea (Retz.) Willd. was then thinned using wood shaving tool to produce sheets with thickness of $0.33 \mathrm{~mm}$. The fiber sheets of Bambusa arundinacea (Retz.) Willd. were cut with a paper cutter at lengths of $2 \mathrm{~mm}, 6 \mathrm{~mm}$ and $12 \mathrm{~mm}$ at 0.5 mm width. Bambusa arundinacea (Retz.) Willd. fiber was soaked with $5 \% \mathrm{NaOH}$ solution with ratio of 1:30 (1 g of bamboo fiber was soaked in $30 \mathrm{ml} 5 \% \mathrm{NaOH}$ solution) at $25^{\circ} \mathrm{C}$ for 24 hours. ${ }^{12}$ Bambusa arundinacea (Retz.) Willd. fiber was washed with distilled water until the abrasive texture achieved. The PH of Bambusa arundinacea (Retz.) Willd. fiber was then neutralized with a mixture of $100 \mathrm{ml}$ distilled water and 5 drops of $\mathrm{CH}_{3} \mathrm{COOH}$ and washed with distilled water to remove $\mathrm{CH}_{3} \mathrm{COOH}$. Bambusa arundinacea (Retz.) Willd. fiber was kept in a closed room at room temperature for 5 days and dried in an oven at $50-60^{\circ} \mathrm{C}$ until dry. ${ }^{12}$

Stages of fabrication of heat-cured acrylic resin plate mould were as follows: The cuvette was smeared with vaseline. $100 \mathrm{~g}$ gypsum powder type 2- and 50-ml water were stirred with a spatula on a rubber bowl and vibrated using vibrator. It was poured into the bottom cuvette to half the height of the cuvette. Type 2 gypsum was waited for intial setting. It was filled with type 3 gypsum with a ratio of 100:30 (100 g powder:30 $\mathrm{ml}$ of water), stirred with a spatula in a rubber bowl, vibrated using vibrator, and finally poured into the bottom cuvette until full. Brass metal master model with a size of $65 \mathrm{~mm} \times 10 \mathrm{~mm} \times 2.5$ $\mathrm{mm}$ was smeared with vaseline and immersed to type 3 gypsum dough in half. It was then waited until final setting. The top cuvette was installed and filled with type 3 gypsum dough until the master model was fully covered with type 3 gypsum. The type 3 gypsum was waited until initial setting. It was then continued with type 2 gypsum filling until full. The cuvette was closed and pressed. The gypsum type 2 has reached the final setting. The cuvette was opened, and the brass metal master model was removed. A mold was then obtained. The mold was smeared with cold mold seal and waited until dry.

Fabrication of sample of heat-cured acrylic resin test plate with the addition of fiber Bambusa arundinacea (Retz.) Willd. required $1 \mathrm{ml}$ heat-cured liquid acrylic resin, which was made in accordance with the manufacturer's ratio. The required amount of heat-cured acrylic resin powder and Bambusa arundinacea (Retz.) Willd. fiber can be seen in Table 1

$1 \mathrm{ml}$ of heat-cured liquid acrylic resin was poured into a porcelain pot. Bambusa arundinacea (Retz.) Willd. fiber was sprinkled into a porcelain pot containing heat-cured liquid acrylic resin until all Bambusa arundinacea (Retz.) Willd. fiber submerged for 5 seconds. The heat-cured acrylic resin powder was gently sprinkled until it seeped into the liquid mixture of the heat-cured acrylic resin and Bambusa arundinacea (Retz.) Willd. fiber. The mixture was then stirred using a wax knife until homogeneous. The porcelain pots were closed and waited dough phase. The dough was put into a mold and covered with cellophane plastic. The cuvette was then closed. The cuvette was pressed using hydraulic press. The cuvette was opened, and the excess was cut. The pressing process was repeated 2-3 times with extra press at the last attempt. Cellophane plastic was removed, and the cuvette was transferred to the handpresss. The cuvette containing the heat-cured acrylic resin mixture underwent curing process. It was done by immersing it in water at room temperature for 30 minutes and boiled until at $100^{\circ} \mathrm{C}$ for 20 minutes. The stove was turned off, and the cuvette was cooled at room temperature. The cuvette was opened, and the heat-cured acrylic resin test plate was removed and cleaned from excess.

The impact strength of heat-cured acrylic resin was measured using a mini impact tester KRY type (Institut Teknologi Sepuluh November (ITS) - Surabaya). The specimen was a heat-cured acrylic resin test plate. It was placed horizontally, and both ends of the specimen were supported. A 750-gram pendulum was positioned at an initial deviation height of $90^{\circ}$. The pendulum was then released that the pendulum continued its swing at maximum 
height until fracture on heat-cured acrylic resin test bar was present. The energy absorbed during a fracture can be obtained by calculating the difference in potential energy from the pendulum before and after testing. The formula for calculating the impact strength was:

$$
\mathrm{Is}=\frac{\mathrm{WxL}(\cos \beta-\cos \alpha)}{\mathrm{A}}
$$

Note:

$\mathrm{W}=$ weight of pendulum $(\mathrm{N})$

$\mathrm{L}=$ pendulum arm length $(\mathrm{m})$

$\alpha=$ initial angle of the pendulum before swinging $\left({ }^{\circ}\right)$

$\beta=$ end angle of the pendulum after swinging $\left({ }^{\circ}\right)$

$\mathrm{A}=$ specimen cross-sectional area $(\mathrm{cm} 2)$

Tukey HSD. The impact strength measurements were carried out at the Metallurgical Laboratory, Institut Teknologi Sepuluh Nopember. To determine the difference of impact strength of heat-cured acrylic resin after adding Bambusa arundinacea (Retz.) Willd fiber, one-way ANOVA statistical test and Tukey HSD advanced statistical test were performed.

\section{RESULTS}

The mean and standard deviations of the impact strength test of the 10 groups of heat-cured acrylic resin can be seen in Table 2.

The test result of one-way ANOVA test showed a probability value of $0.000(p<0.005)$. Thus, it can be interpreted that there were significant differences in all sample groups. To find out the differences between sample groups, the Tukey HSD test was performed.

\section{DISCUSSION}

Based on Table 2, all groups have a higher average impact strength of heat-cured acrylic resin than the minimum impact strength value of a denture base material, which is $1,500-1,700 \mathrm{~N} / \mathrm{m}^{2}{ }^{3}$ The results of one-way ANOVA data analysis shows that there were significant differences in the impact strength of heat-cured acrylic resin in all sample groups. This can be interpreted that the addition of Bambusa

Table 1. Weight of heat-cured acrylic resin powder and Bambusa arundinacea (Retz.) Willd. fiber

\begin{tabular}{lcc}
\hline Group & $\begin{array}{c}\text { Heat-cured } \\
\text { acrylic resin } \\
\text { powder }(\text { gram })\end{array}$ & $\begin{array}{c}\text { Bambusa arundinacea } \\
\text { (Retz.) Willd. fiber } \\
\text { (gram) }\end{array}$ \\
\hline 1 & 2.3 & 0 \\
2 & 2.231 & 0.069 \\
3 & 2.162 & 0.138 \\
4 & 2.093 & 0.207 \\
5 & 2.231 & 0.069 \\
6 & 2.162 & 0.138 \\
7 & 2.093 & 0.207 \\
8 & 2.231 & 0.069 \\
9 & 2.162 & 0.138 \\
10 & 2.093 & 0.207 \\
\hline
\end{tabular}

arundinacea (Retz.) Willd. fiber can affect the impact strength of heat-cured acrylic resin.

Results of Tukey HSD data analysis (Table 3) show that in group 1 (control), there was a significant difference against group 2 and group 3. The significant difference was in the form of reduced impact strength of heat-cured acrylic resin with the addition of Bambusa arundinacea (Retz.) Willd. fiber in group 2 by $59 \%$ and group 3 by $50 \%$ against group 1 (control). The reduction on impact strength was influenced by the presence of wax and hemicellulose content in Bambusa arundinacea fiber (Retz.) Willd. fiber. The presence of wax and hemicellulose content can reduce interface bonding between Bambusa arundinacea (Retz.) Willd. fiber and heat-cured acrylic resin polymer matrices, reducing the impact strength. ${ }^{14}$

The reduction of impact strength of heat-cured acrylic resin after the addition of Bambusa arundinacea (Retz.) Willd. fiber was caused by the remaining content of wax and hemicellulose in Bambusa arundinacea fibers (Retz.) Willd. fiber. Due to the remaining content of wax and hemicellulose, the surface roughness of Bambusa arundinacea (Retz.) Willd. fiber was reduced. The reduction of surface roughness reduced the interface bonding between Bambusa arundinacea (Retz.) Willd. fiber and the heatcured acrylic resin polymer matrix, therefore reducing the impact strength. To achieve an excellent surface roughness of Bambusa arundinacea (Retz.) Willd. fiber, alkalization was required. The research result suggested that alkalization process was not optimal considering that the $5 \% \mathrm{NaOH}$ concentration was not sufficient to remove wax and hemicellulose. ${ }^{13}$ The $10 \% \mathrm{NaOH}$ concentration

Table 2. Mean and standard deviations of the test impact strength of heat-cured acrylic resin

\begin{tabular}{cccc}
\hline Group & $\mathrm{n}$ & Mean $\left(\mathrm{N} / \mathrm{m}^{2}\right)$ & $\mathrm{SD}$ \\
\hline 1 & 4 & $4,468.25$ & 329.50 \\
2 & 4 & $2,817.00$ & 633.29 \\
3 & 4 & $2,982.50$ & 381.62 \\
4 & 4 & $3,478.25$ & 330.50 \\
5 & 4 & $4,138.75$ & 329.50 \\
6 & 4 & $4,303.50$ & 380.47 \\
7 & 4 & $4,632.75$ & 537.66 \\
8 & 4 & $4,468.25$ & 329.50 \\
9 & 4 & $4,797.50$ & 329.00 \\
10 & 4 & $5,126.00$ & 629.11 \\
\hline
\end{tabular}

Note:

$\mathrm{n} \quad$ : Number of samples

SD : Standard deviation

Group 1 : Heat-cured acrylic resin plate (control).

Group 2 : Heat-cured acrylic resin plate with Bambusa arundinacea fiber at $2 \mathrm{~mm}$ length and $3 \mathrm{wt} \%$ weight.

Group 3 : Heat-cured acrylic resin plate with Bambusa arundinacea fiber at $2 \mathrm{~mm}$ length and $6 \mathrm{wt} \%$ weight.

Group 4 : Heat-cured acrylic resin plate with Bambusa arundinacea fiber at $2 \mathrm{~mm}$ length and $9 \mathrm{wt} \%$ weight.

Group 5 : Heat-cured acrylic resin plate with Bambusa arundinacea fiber at $6 \mathrm{~mm}$ length and $3 \mathrm{wt} \%$ weight.

Group 6 : Heat-cured acrylic resin plate with Bambusa arundinacea fiber at $6 \mathrm{~mm}$ length and $6 \mathrm{wt} \%$ weight.

Group 7 : Heat-cured acrylic resin plate with Bambusa arundinacea fiber at $6 \mathrm{~mm}$ length and $9 \mathrm{wt} \%$ weight.

Group 8 : Heat-cured acrylic resin plate with Bambusa arundinacea fiber at $12 \mathrm{~mm}$ length and $3 \mathrm{wt} \%$ weight.

Group 9 : Heat-cured acrylic resin plate with Bambusa arundinacea fiber at $12 \mathrm{~mm}$ length and $6 \mathrm{wt} \%$ weight.

Group 10 : Heat-cured acrylic resin plate with Bambusa arundinacea fiber at $12 \mathrm{~mm}$ length and $9 \mathrm{wt} \%$ weight. 
Indonesian Journal of Dental Medicine Volume 1 Issue 2 2018; 81-85

Table 3. Results of Tukey HSD tests

\begin{tabular}{|c|c|c|c|c|c|c|c|c|c|c|}
\hline Group & 1 & 2 & 3 & 4 & 5 & 6 & 7 & 8 & 9 & 10 \\
\hline 1 & & $0.000 *$ & $0.001 *$ & 0.081 & 0.985 & 1.000 & 1.000 & 1.000 & 0.985 & 0.527 \\
\hline 2 & & & 1.000 & 0.519 & $0.006^{*}$ & $0.001 *$ & $0.000 *$ & $0.000 *$ & $0.000 *$ & $0.000 *$ \\
\hline 3 & & & & 0.838 & $0.023^{*}$ & $0.006^{*}$ & $0.000 *$ & $0.001 *$ & $0.000 *$ & $0.000 *$ \\
\hline 4 & & & & & 0.521 & 0.233 & $0.024 *$ & 0.081 & $0.006^{*}$ & $0.000 *$ \\
\hline 5 & & & & & & 1.000 & 0.840 & 0.985 & 0.524 & 0.083 \\
\hline 6 & & & & & & & 0.985 & 1.000 & 0.840 & 0.237 \\
\hline 7 & & & & & & & & 1.000 & 1.000 & 0.842 \\
\hline 8 & & & & & & & & & 0.985 & 0.527 \\
\hline 9 & & & & & & & & & & 0.985 \\
\hline 10 & & & & & & & & & & \\
\hline
\end{tabular}

Note : Significant differences

in the alkalization process was considered the most ideal because at $10 \%, 15 \%$, and $25 \% \mathrm{NaOH}$ concentration, there was no hemicellulose present on the surface of bamboo fiber. Whereas, at $6 \%$ and $8 \% \mathrm{NaOH}$ concentration, remaining hemicellulose was found on bamboo fiber. ${ }^{15}$

The reduction of impact strength was likely to occur because the impact load applied exceeds the interfacial bond strength between the heat-cured acrylic resin polymer matrix and Bambusa arundinacea (Retz.) Willd. fiber Reduction of interfacial bond strength may cause debonding to occur between heat-cured acrylic resin polymer matrix and Bambusa arundinacea (Retz.) Willd. fiber Heftier Bambusa arundinacea (Retz.) Willd. fiber was less able to receive the impact pressure, so the impact strength of heat-cured acrylic resin added with Bambusa arundinacea (Retz.) Willd. fiber was reduced.

Reduction of impact strength of Polylactic Acid (PLA) after the addition of kenaf fibers occurred due to the insufficient number of PLA polymer matrix to effectively transfer the stress to kenaf fiber during impact, reducing the stress absorption of kenaf fiber. During the impact, the stress is transferred from the PLA polymer matrix to kenaf fibers which can act as the barrier to transfer the impact stress load from a small portion of the polymer matrix. Smaller energy adsorption by the kenaf fiber causes higher crack propagation and crack initiation, causing debonding. ${ }^{16}$ The reduction of impact strength and transverse strength in the heat-cured acrylic resin groups with the addition of Hibiscus sabdariffa fiber compared to the control group occurred due to inadequate fiber weight of Hibiscus sabdariffa. If the fiber weight of Hibiscus sabdariffa was inadequate, it can break the bonding of acrylic resin polymer, reducing the ability to transfer load of the entire mass and may lead to failure of mechanical strength of heat-cured acrylic resin. ${ }^{17}$

The reduction of impact strength of heat-cured acrylic resin after the addition of Bambusa arundinacea (Retz.) Willd. fiber was possibly caused by weak fiber strength which was influenced by the length of Bambusa arundinacea (Retz.) Willd. fiber. The length of Bambusa arundinacea (Retz.) Willd. fiber in group 2 and group 3 was $2 \mathrm{~mm}$. It was less likely for the fiber to be able to receive the applied impact pressure. Thus, bamboo fiber fractures occurred. Fracture of Bambusa arundinacea (Retz.) Willd. fiber can cause microcracks, causing the impact strength of heat-cured acrylic resins to decrease.

The strength of bamboo fiber ${ }^{18}$ can contribute the reduction impact strength. The strength of bamboo fiber is affected by the length of $i^{16}$. The strength of bamboo fibers weakens when excessive pressure is applied, causing bamboo fiber to fracture. Fractured bamboo fiber can off from the Cement By-Pass Dust polymer matrix. ${ }^{18}$ Bamboo fiber that off from Polylactic Acid (PLA) polymer matrix leaves hole, exposing the bamboo. ${ }^{19}$ Holes between bamboo fiber and epoxy polymer matrix result more microcracks as the impact strength proceeds, creating spaces when crack propagation occurs. Due to the amount of spaces, the epoxy impact strength reduces. ${ }^{12}$ Another cause of reduced impact strength of heat-cured acrylic resins other than those caused by Bambusa arundinacea (Retz.) Willd. fiber fracture was the failure of acrylic resin polymer matrix to effectively transfer loads to the Bambusa arundinacea (Retz.) Willd. fiber, which was relatively short ( $2 \mathrm{~mm}$ ). Matrix of acrylic resin polymer which fails to transfer the load effectively to Bambusa arundinacea (Retz.) Willd. fiber burdens the acrylic resin polymer matrix. with the entire load. It proves that a relatively short bamboo fiber added to polyester caused a lower impact strength compared to polyester only (control). ${ }^{20}$

Results of Tukey HSD data analysis (Table 3) shows that there was a significantly improvement on the impact strength of group 2 against group 5 and group 8, group 3 against group 6 and group 9, and group 4 against group 7 and group 10. The reduction of impact strength of heat-cured acrylic resin after the addition of Bambusa arundinacea (Retz.) Willd fiber was affected by the length of Bambusa arundinacea (Retz.) Willd. fiber Longer of Bambusa arundinacea (Retz.) Willd. fiber length resulted in a better stress transfer from heat-cured acrylic resin polymer matrix to the Bambusa arundinacea (Retz.) Willd. fiber

The impact strength of PLA increases after the addition of bamboo fiber. Longer bamboo fiber allows more energy loss on bamboo fiber that is pulled out of the PLA polymer matrix PLA. This happens because the diameter of fixed bamboo fiber and the longer bamboo fiber contributes to a 
Indonesian Journal of Dental Medicine Volume 1 Issue 2 2018; 81-85

greater fiber aspect ratio and contributes to a greater stress transfer between the bamboo fiber and the PLA polymer matrix. ${ }^{21}$

Results of Tukey HSD data analysis (Table 3) show that there was no significant increase on the impact strength of group 2 against group 3 and group 4, group 5 against group 6 and group 7, and group 8 against group 9 and group 10. Addition of Bambusa arundinacea (Retz.) Willd. fiber to the groups resulted in an insignificant increase on impact strength. Willd. fiber Heftier Bambusa arundinacea (Retz.) Willd. fiber. A higher position suggests lesser bamboo pores so that the porosity was reduced. If the porosity of bamboo fiber is low, the interfacial bonding reaction is good. This occurred because of the weight of a bamboo fiber composed of bamboo fiber composition and pores or holes of bamboo fibers. Lighter bamboo fiber weight indicates the presence of high porosity due too many pores. ${ }^{18}$

Impact strength can increase respective to the bamboo fiber weight $(20 \mathrm{wt} \%)$ added to CBPD. It happens due to good interfacial bonding reaction and creates an effective barrier for pinning and crack bifurcation. ${ }^{18}$

The results of this study indicate that the addition of Bambusa arudinacea (Retz.) Willd. fiber increases the impact strength of heat-cured acrylic resin as the length and weight of the Bambusa arudinacea (Retz.) Willd. fiber increase.

\section{REFERENCES}

1. Anusavice KJ, Shen C, Rawls HR. Phillips' science of dental materials. $12^{\text {th }}$ ed, Missouri: Elsevier Saunders. 2013. p. 61, 460, 475-85.

2. Van Noort R. Introduction to dental materials, $4^{\text {th }}$ ed. London:Mosby. 2013. p. 47, 175-9.

3. Van Fraunhofer JA. Dental materials at a glance, $2^{\text {nd }}$ ed, London: Wiley Blackwell. 2013. p. 45, 47, 49, 53.

4. Naji S. A clinical study of complete and partial denture fracture at four hospitals in Iraq. Mustansiria Dental Journal. 2012. 9:201-17.

5. McCabe JF, Walls, A. Applied dental materials. $9^{\text {th }}$ ed. Oxford:Blackwell Publishing. 2008. p. 11, 111-20.

6. El-Sheikh AM, Al-Zahrani SB. Causes of denture fracture: a survey. Saudi Dental Journal. 2006. 18:149-54.

7. Freilich MA, Meiers JC, Duncan JP, Goldberg AJ. Fiber-reinforced composites in clinical dentistry. $1^{\text {st }}$ ed. Hongkong:Quintessence Publishing. 2006. 18:16.
8. Biswas S, Ahsan Q, Cenna A, Hasan M, Hassan A. Physical and mechanical properties of jute, bamboo and coir natural fiber. Fibers and Polymers. 2013. 14:1762-67.

9. Liu D, Song J, Anderson DP, Chang P, Hua Y. Bamboo fiber and its reinforced composites: structure and properties. Cellulose. 2012. 19: 1449-80.

10. Okubo K, Fujii T, Yamamoto Y. Development of bamboobased polymer composites and their mechanical properties. Composites. 2004. 1:377-83.

11. Wang C, Ying S. A novel strategy for the preparation of bamboo fiber reinforced polypropylene composites. Fibers and Polymers. 2014. 15:117-25.

12. Gupta SK. A study on mechanical behavior of bamboo fiber based on polymer composites. Bachelor of Technology thesis. Rourkella:National Institute of Technology. 2014. p. 4, 14,

13. Oleiwi JK, Salih SI, Fadhil HS. Effect of siwak and bamboo fibers on tensile properties of self-cure acrylic resin used for denture applications. Material Science \& Engineering. 2017. 6:1-6.

14. Pai RA, Jagtap RN. Surface morphology \& mechanical properties of some unique natural fiber reinforced polymer composites-a review. Material Environment. 2015. 6:904.

15. Chen H, Chen H, Wang G, Yu Z, Shi SQ. Tensile properties of bamboo in different sizes. Journal Wood Sciences. 2015. 61:552-61.

16. Tawakkal I, Rosnita AT, Abdan K, Ling CN. Mechanical and physical properties of kenaf derived cellulose (KDC)-filled polylactic acid (PLA) composites. BioResources. 2012. 7:1643-55.

17. Okeke KN, Vahed A, Singh S. Improving the strength properties of denture base acrylic resins using hibiscus sabdariffa natural fiber. Journal of International Dental and Medical Research. 2018. 11:248-54.

18. Gupta A, Ajit K, Amar P, Sandhyarani B. Effect of filler content and alkalization on mechanical and erosion wear beaviour of CBPD filled bamboo fiber composites. Journal of Surface Engineered Materials and Advanced Technology. 2012. 2:149-57.

19. Kim HJ, Seo DW, Lim JK, Fujii T. Tensile properties and water absorbtion beahaviour of bamboo fiber reinforced composites. Key Engineering Materials. 2006. 306-308:41722.

20. Wong KJ, Zahi S, Low KO, Lim CC. Fracture characterization of short bamboo fibre reinforced polyester composite. Materials and Design. 2010. 1:4147-54.

21. Tokoro R, Vu DM, Okubo K, Tanaka T, Fujii T, Fujiura T. How to improve mechanical properties of polylactic acid with bamboo fibers. Journal Materials Sciences. 2007. 43:775-87. 